\title{
Musth and urinary testosterone concentrations in the African elephant (Loxodonta africana)*
}

\author{
Joyce H. Poole, L. H. Kasman†, E. C. Ramsay† and B. L. Lasley $\dagger$ \\ Sub-department of Animal Behaviour, Madingley, Cambridge CB3 8AA, U.K. and \\ †Zoological Society of San Diego, P.O. Box 551, San Diego, California 92112, U.S.A.
}

\begin{abstract}
Summary. Urine samples were obtained from free-ranging African elephants that were considered to be in and out of musth. Testosterone concentrations, measured by radioimmunoassay were significantly greater in males that were in or around the time of behavioural musth. This study supports a correlation between the observed behavioural characteristics of musth and urinary testosterone levels.
\end{abstract}

\section{Introduction}

The phenomenon of musth in the male Asian elephant (Elephas maximus) has long been recognized (Darwin, 1874; Evans, 1901) and has now been identified in the African genus, Loxodonta (Poole \& Moss, 1981). Musth, which has been likened to rutting behaviour in ungulates (Eisenberg, McKay \& Jainudeen, 1971), refers to a set of visible physical and behavioural characteristics displayed periodically by adult male elephants (Poole \& Moss, 1981). The most obvious manifestations in Asian and African elephants are a sharp rise in aggressive behaviour, copious secretions from and enlargement of the temporal glands, and the frequent discharge of urine (Jainudeen, McKay \& Eisenberg, 1972a; Poole \& Moss, 1981). During musth, free-living male elephants search out and associate with females (Eisenberg et al., 1971; Poole \& Moss, 1981).

Amongst free-ranging African elephants, the phenomenon of musth is central to understanding the mating system of elephants: males in musth experience a temporary rise in dominance rank; musth males are more successful at guarding and mating oestrous females than are non-musth males; high-ranking musth males appear to be able to inhibit musth in lower ranking individuals; oestrous females attempt to maintain proximity to musth males but never to non-musth males (Poole, 1982).

In the Asiatic elephant, changes in plasma testosterone levels with musth have been described (Jainudeen, Katongole \& Short, 1972b). Although it is possible to collect blood samples from domesticated animals (Jainudeen et al., 1972b), the collection of a large number of blood samples from free-ranging elephants is not feasible. In the present study, carried out in Amboseli National Park, Kenya, we therefore attempted to assess changes in urinary testosterone levels with observed musth behaviour.

* Reprint requests to L. H. Kasman, Research Department, San Diego Zoo, P.O. Box 551, San Diego, California 92112, U.S.A.

† Present address: Oklahoma City Zoo, Oklahoma City, Oklahoma 73111, U.S.A. 


\section{Materials and Methods}

Study area, subjects and urine collection

The Amboseli National Park in Kenya covers an area of $390 \mathrm{~km}^{2}$ and consists of semi-arid, wooded, bushed, and open grasslands interspersed with a series of permanent swamps. The surrounding area, making up an ecosystem of about $3000 \mathrm{~km}^{2}$, is semi-arid savannah in which water availability is seasonal (Western, 1975). This ecosystem is inhabited by a free-ranging population of elephants numbering 600 individuals, which have been under observation by J. H. Poole and C. J. Moss since September 1975. This population includes 162 sexually mature males. All adults of both sexes and most juveniles are individually known.

Urine samples were collected from 26 adult males estimated to be at least 25 years of age. Male elephants reach puberty between 14 and 17 years of age (Laws, Parker \& Johnston, 1975). Elephants continue to grow throughout life and age can be estimated from shoulder height (Laws, 1966). Hind footprint length has been found to be a good predictor of shoulder height (Western, Moss \& Georgiadis, 1983) and elephants in this study were aged by this method.

The animals were observed closely during the year that urine samples were collected (June 1980-July 1981) and a detailed account was kept of each animal's behaviour, associations and sexual state. Individuals that periodically come into musth have been termed "socially mature" males. Younger adult males in the Amboseli population do not come into musth although they do have sexually active periods and can mate successfully (Poole, 1982). These males have been termed "socially non-mature."

The urine was collected by aspiration from the ground into a $20-\mathrm{ml}$ syringe. Collection usually took place between $07: 00$ and $09: 00 \mathrm{~h}$. The time urine took to soak into the ground varied with soil type, but samples were usually collected within $1 \mathrm{~min}$ after urination, and filtered to remove debris whenever possible. The samples were stored in 20 -ml glass containers and usually frozen within $4 \mathrm{~h}$ of collection. The samples were shipped on solid $\mathrm{CO}_{2}$ to the endocrine laboratory at the San Diego Zoo for analysis.

The samples collected were from animals that were placed into one of five categories: (A) males showing physical signs of musth; (B) males that were not showing signs of musth but were in association with females; (C) males that periodically showed musth but were not showing signs of musth and were in association with other males; (D) mature males that were neither in musth nor in association with female groups at the time of collection, but came into musth within 1 month; and (E) mature, sexually active males, not in musth at the time of sample collection, in association with females, had already been seen in musth during that particular sexually active period and came into musth again within 1 week from the date of sample collection. In all, 52 urine samples were collected from 26 different males.

The study by Jainudeen et al. (1972b) showed that plasma testosterone levels increase dramatically with the onset of musth in Asian elephants and so one-tailed tests of statistical significance were considered justified.

\section{Testosterone assay}

Method. Urinary testosterone concentrations were measured by a method similar to that described by Czekala, Hodges, Gause \& Lasley (1980). All samples were analysed for creatinine concentration (Taussky, 1954) to allow for the correction of the variations in concentrations of the urine samples. Urine samples containing $<0 \cdot 1 \mathrm{mg}$ creatinine $/ \mathrm{ml}(\mathrm{N}=2)$ were considered too dilute for further evaluation. Enzymic hydrolysis of urine samples $(0.2 \mathrm{ml})$ was accomplished by first diluting the urine with an equal volume of assay buffer $\left(0 \cdot 1 \mathrm{M}-\mathrm{NaPO}_{4}, 0 \cdot 9 \%(\mathrm{w} / \mathrm{v}) \mathrm{NaCl}, 0 \cdot 1 \%\right.$ $\mathrm{NaN}_{4}, 0.1 \%$ gelatin, $\mathrm{pH} 5$ ), adding $0.02 \mathrm{ml} \beta$-glucuronidase-arylsulphatase (BoehringerMannheim, West Germany) and incubating for $24 \mathrm{~h}$ at $37^{\circ} \mathrm{C}$. Methodological loss was monitored and accounted for by adding 2000 c.p.m. repurified $\left[{ }^{3} \mathrm{H}\right]$ testosterone before extraction with $8.0 \mathrm{ml}$ 
freshly opened diethyl ether (Mallinckrodt, St Louis, Missouri). The aqueous phase was separated by snap-freezing in methanol-solid $\mathrm{CO}_{2}$ and the ether extracts were reduced to $0.5 \mathrm{ml}$ under a nitrogen stream at $40^{\circ} \mathrm{C}$. Iso-octane $(1.0 \mathrm{ml})$ was added at this time to limit the amount of adherence of steroid to the vial, and the volume was reduced to remove the residual ether (Ramsay, Lasley \& Stabenfeldt, 1981).

Chromatography on celite columns was performed on each extractant as previously described (Czekala et al., 1980) and aliquots of each eluate were taken for recovery and radioimmunoassay using the Abraham S-791 No. 7 antiserum. A total volume of $0.7 \mathrm{ml}$ including 9000 c.p.m. $\left[1,2,6,7^{3} \mathrm{H}\right]$ testosterone (sp. act. $94 \mathrm{Ci} / \mathrm{mmol}$; New England Nuclear, Boston, Massachusetts), in assay buffer, $\mathrm{pH} 7$, was incubated overnight at $15^{\circ} \mathrm{C}$.

Separation of antibody-bound from free steroid was achieved by the addition of $0.2 \mathrm{ml}$ charcoal-dextran $(0.65 \%$ and $0.065 \%$, respectively) in assay buffer ( $\mathrm{pH} 7)$. The sensitivity of all assays was $5 \mathrm{pg} /$ tube because this was the smallest amount of pure standard that gave values more than two s.d. less than the mean of the zero tubes. Water blanks were $<5 \mathrm{pg} /$ tube.

The intra-assay precision, as expressed by coefficient of variation (CV), was obtained by evaluating 8 replicate urine samples in the same assay giving a value of $3 \cdot 1 \%$ over the range 48 to $51 \%$ bound. The interassay $\mathrm{CV}$ for controls in the middle of the range was $9 \%(n=5)$. The recovery of tritiated testosterone after celite chromatography averaged $79 \pm 0.3 \%$ (s.e.m.; $n=60$ ).

Validation. Specificity of the antiserum for determining urinary testosterone was determined empirically since it may not be possible to predict the potential contributory components in elephant urine. Serial dilutions of hydrolysed elephant urine were assayed for testosterone and showed a parallel dose-response to the pure testosterone standards. Celite co-chromatography of $\left[{ }^{3} \mathrm{H}\right]$ testosterone and hydrolysed elephant urine is shown in Text-fig. 1. Parallelism of the pure radiolabelled testosterone and immunoreactivity indicates that this separation procedure is able to separate urinary testosterone from other immunoreactive components and that testosterone is the major immunoreactive component.

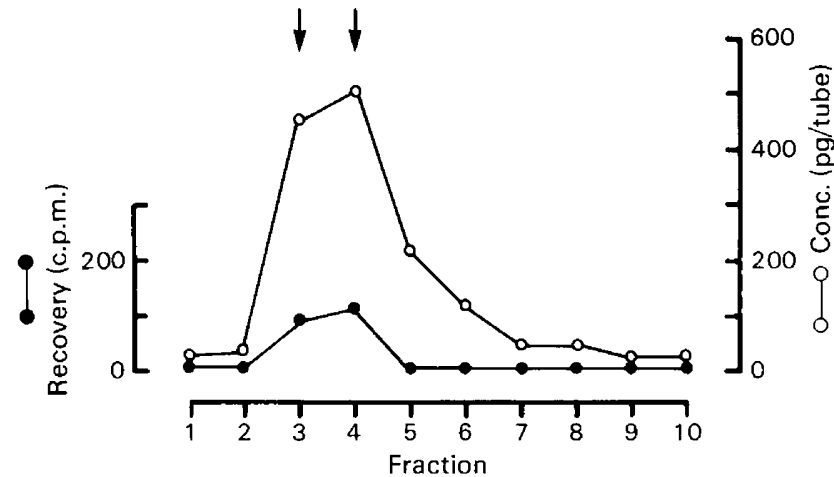

Text-fig. 1. Celite co-chromatography of male elephant urine extract showing recovery of added $\left[{ }^{3} \mathrm{H}\right]$ testosterone and concentrations of testosterone as measured by RIA. Arrows indicate the characterized elution pattern of pure testosterone.

Co-chromatography by high-pressure liquid chromatography (HPLC) was performed by hydrolysis of $0.5 \mathrm{ml}$ of urine, addition of 2000 c.p.m. each $\left[{ }^{3} \mathrm{H}\right]$ testosterone and $\left[{ }^{3} \mathrm{H}\right]$ dihydrotestosterone and extraction as described previously. The dried sample was reconstituted in $0.055 \mathrm{ml}$ methanol (Mallinckrodt) before injection onto a $4.6 \times 250 \mathrm{~mm}$ Lichrosorb $\mathrm{C}_{18}$ column (Altex Scientific, Berkeley, California) using acetonitrile : water $(40: 60 \mathrm{v} / \mathrm{v})$ as the isocratic system. Eluate fractions were collected at $0 \cdot 5$-min intervals for $15 \mathrm{~min}$ then at $0 \cdot 3-\mathrm{min}$ intervals for an additional 21 min (flow rate consistently at $1.0 \mathrm{ml}$ per min). The fractions were evaporated under nitrogen, reconstituted in $1.0 \mathrm{ml}$ assay buffer $(\mathrm{pH} 7)$ and divided into aliquots; $0.4 \mathrm{ml}$ for testosterone assay, 
and $0.4 \mathrm{ml}$ for monitoring recovery of labelled hormone. The results are shown in Text-fig. 2 and substantiate the indication that testosterone was, in fact, the major component. A second peak which co-eluted with $\left[{ }^{3} \mathrm{H}\right]$ dihydrotestosterone, was present and would be the only contaminating factor to the testosterone measurements if celite chromatography were not employed.

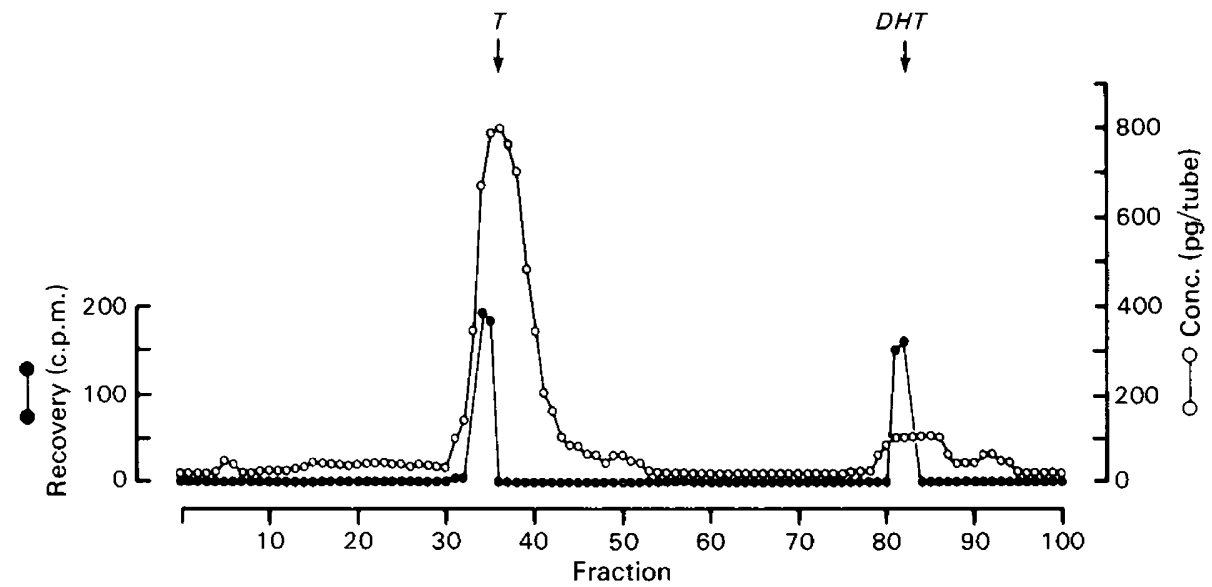

Text-fig. 2. High-performance liquid co-chromatography of male elephant urine extract not separated by celite chromatography. Arrows indicate the characterized elution patterns of the pure hormones, testosterone (T) and dihydrotestosterone (DHT).

\section{Results}

In 5 of the 26 animals studied (Nos 78, 80,97, 99 \& 107), samples were collected when the elephants were in musth and not in musth. All 5 individuals showed markedly higher levels $(P=0.004$, nonpaired $t$-test) of urinary testosterone (ng/mg creatinine) during musth (range 164-393) than during non-musth periods (range 39-153).

The results for all the samples are shown in Table 1. Groups were statistically compared using a non-paired group $t$ test. Musth males (Group A) had statistically higher testosterone levels than did those in Groups B and C (non-musth) $(P=0.04$ and 0.001 , respectively).

Non-musth, sexually active males (Group B) had statistically higher levels than did non-musth, sexually inactive males (Group C; $P=0.01$ ). The males in Groups D and $E$ had statistically higher testosterone levels than did those in Group $C(P=0.0001$ and 0.003 , respectively).

\section{Discussion}

The study by Jainudeen et al. (1972b) demonstrated that musth in the Asian elephant is associated with, and possibly caused by a marked increase in testicular secretion. They also suggested that musth may be induced by exposure to oestrous females. Studies on African elephants show that individual testicular testosterone concentrations are highly variable (3-490 ng/100 g testicular tissue; Short, Mann \& Hay, 1967; Buss \& Johnson, 1967). However, in both these studies there was a large age range amongst the subjects. In addition, their past histories were unknown and the phenomenon of musth in these elephants had not been recognized. Although no relations between steroid concentration and behavioural state were established, the results did suggest that the variations could reflect inherent cyclicity in individual reproductive activity. 
Table 1. Testosterone concentrations ( $\mathrm{ng} / \mathrm{mg}$ creatinine) in urine collected from male African elephants in musth (Group A), sexually active but not in musth (Group B), sexually inactive and not in musth (Group C), pre-musth (Group D), and those mature, sexually active, not in musth at the time of collection, in association with females, had already been seen in musth during that sexually active period and came into musth again 1 week from the date of sample collection (Group E)

\begin{tabular}{|c|c|c|c|c|c|c|c|c|c|}
\hline \multicolumn{2}{|c|}{ Group A } & \multicolumn{2}{|c|}{ Group B } & \multicolumn{2}{|c|}{ Group C } & \multicolumn{2}{|c|}{ Group D } & \multicolumn{2}{|c|}{ Group E } \\
\hline Male & $\begin{array}{l}\text { Testost- } \\
\text { erone }\end{array}$ & Male & $\begin{array}{l}\text { Testost- } \\
\text { erone }\end{array}$ & Male & $\begin{array}{l}\text { Testost- } \\
\text { erone }\end{array}$ & Male & $\begin{array}{l}\text { Testost- } \\
\text { erone }\end{array}$ & Male & $\begin{array}{l}\text { Testost- } \\
\text { erone }\end{array}$ \\
\hline 99 & 164.7 & 149 & 76.0 & 107 & $39 \cdot 2$ & 44 & $176 \cdot 2$ & 46 & 91.9 \\
\hline 78 & $181 \cdot 4$ & 97 & 95.6 & 51 & $41 \cdot 1$ & 107 & $181 \cdot 7$ & 57 & $142 \cdot 3$ \\
\hline 13 & 193.5 & 91 & $141 \cdot 8$ & 22 & $41 \cdot 5$ & 57 & $303 \cdot 6$ & 150 & $223 \cdot 0$ \\
\hline 97 & $194 \cdot 0$ & 147 & $205 \cdot 5$ & 28 & $47 \cdot 1$ & 114 & $361 \cdot 3$ & 80 & $248 \cdot 5$ \\
\hline 107 & 226.0 & 132 & 214.6 & 99 & 58.0 & & & & \\
\hline 114 & $264 \cdot 2$ & & & 41 & $67 \cdot 3$ & & & & \\
\hline 119 & 313.6 & & & 154 & 69.9 & & & & \\
\hline 80 & $393 \cdot 3$ & & & 80 & 73.7 & & & & \\
\hline & & & & 44 & 77.9 & & & & \\
\hline & & & & 126 & $80 \cdot 0$ & & & & \\
\hline & & & & 45 & $99 \cdot 2$ & & & & \\
\hline & & & & 78 & 153.0 & & & & \\
\hline & & & & 10 & $162 \cdot 4$ & & & & \\
\hline Mean & $241 \cdot 3$ & & 146.7 & & 77.7 & & $225 \cdot 7$ & & 176.4 \\
\hline s.d. & 78.4 & & 62.6 & & 39.7 & & $91 \cdot 7$ & & $72 \cdot 3$ \\
\hline s.e.m. & $27 \cdot 7$ & & $38 \cdot 0$ & & 11.0 & & 45.9 & & $36 \cdot 1$ \\
\hline
\end{tabular}

In the present study the physical and behavioural characteristics associated with musth in African elephants have been related to levels of urinary testosterone. Behavioural (Poole, 1982) and hormonal data indicate that adult male elephants over the age of 25 have sexually active periods, but that some individuals experience heightened periods of sexual activity, i.e. musth. Males that were considered to be 'pre-musth' (Group D) exhibited changes in behaviour (i.e. postural, agonistic and habitat use; Poole, 1982) and had high levels of urinary testosterone. These findings are in agreement with those of Jainudeen et al. (1972b) who reported elevated plasma testosterone concentrations and behavioural changes in Asian elephants several weeks before the onset of musth. Sexually active 'inter-musth' males (Group E) also showed high urinary testosterone values. Poole (1982) suggested that musth in these males was being inhibited by the presence of higher ranking males in musth.

These data suggest that the physical manifestations of musth may be predicted by means of regular urine analysis. In view of the fact that few males are kept in captivity because of management problems, and the need for breeding programmes to perpetuate the species, endocrine monitoring could help to indicate when males should be controlled physically, or possibly by chemical means, before musth was observed.

We thank the Office of the President, Government of Kenya, for research clearance and the Ministry of Tourism and Wildlife and Bob Oguya, the warden, for permission to work in Amboseli National Park. Financial support for the study was provided by the New York Zoological Society, Zoological Society of San Diego, Smith College, Sigma Xi Society, and Kings College, Cambridge. Facilities were made available by the Sub-department of Animal Behaviour, University of Cambridge and by the San Diego Zoo. We also thank Julie Feaver, Robert Hinde, Keith Hodges, Cynthia Moss and Liza Steele for helpful criticisms on drafts of this paper; and Sharon Dinwiddie for preparation of the manuscript. 


\section{References}

Buss, I.O. \& Johnson, O.W. (1967) Relationship of Leydig cell characteristics and intratesticular testosterone levels to sexual activity in the African elephant. Anat. Rec. 157, 191-192.

Czekala, N.M., Hodges, J.K., Gause, G.E. \& Lasley, B.L. (1980) Annual circulating testosterone levels in captive and free-ranging male armadillos (Dasypus novemcinctus). J. Reprod. Fert. 59, 199-204.

Darwin, C. (1874) The Descent of Man and Selection in Relation to Sex, 2nd edn. A.L. Burt Company, New York.

Eisenberg, J.F., McKay, G.M. \& Jainudeen, M.R. (1971) Reproductive behaviour of the Asiatic elephant (Elephas maximus L.). Behaviour 38, 193-217.

Evans, G.H. (1901) A Treatise on Elephants. Government Printing, Burma.

Jainudeen, M.R., McKay, G.M. \& Eisenberg, J.F. (1972a) Observations on musth in the domesticated Asiatic elephant. Mammalia 36, 247-261.

Jainudeen, M.R., Katongole, C.B. \& Short, R.V. (1972b) Plasma testosterone levels in relation to musth and sexual activity in the male Asiatic elephant, Elephas maximus. J. Reprod. Fert. 29, 99-103.

Laws, R.M. (1966) Age criteria for the African elephant, Loxodonta a. africana. E. Afr. Wildl. J. 4, 1-37.

Laws, R.M., Parker, I.S.C. \& Johnston, R.C.B. (1975)
Elephants and Their Habitats. The Ecology of Elephants in North Bunyoro, Uganda. Clarendon Press, Oxford.

Poole, J.H. (1982) Musth and male-male competition in the African elephant. Ph.D. thesis, University of Cambridge.

Poole, J.H. \& Moss, C.J. (1981) Musth in the African elephant, Loxodonta africana. Nature, Lond. 292, 830831.

Ramsay, E.C., Lasley, B.L. \& Stabenfeldt, G.H. (1981) Monitoring the estrous cycle of the Asian elephant (Elephas maximus), using urinary estrogens. Am. J. vet. Res. 42, 256-260.

Short, R.V., Mann, T. \& Hay, M.F. (1967) Male reproductive organs of the African elephant, Loxodonta africana. J. Reprod. Fert. 13, 516-536.

Taussky, H.H. (1954) A microcolorimetric determination of creatinine in urine by the Jaffee reaction. $J$. biol. Chem. 208, 853-861.

Western, D. (1975) Water availability and its influence on the structure and dynamics of a savannah large mammal community. E. Afr. Wildl. J. 13, 265-268.

Western, D., Moss, C.J. \& Georgiadis, N. (1983) The growth rate and age structure of the Amboseli elephant population based on footprint measurements. J. Wildl. Mgmt (in press).

Received 3 June 1983 